Pereira, H. G. \& Valentine, R. C. (1958). J. gen. Microbiol. 19, 178-181

\title{
Infectivity Titrations and Particle Counts of Adenovirus Type 5
}

\author{
By H. G. PFiReira and R. C. VALENTINE \\ National Institute for Medical Research, Mill Hill, London, N.W. 7
}

SUMMARY: Infectivity titrations and electron microscopic spray counts were performed on purified preparations of adenovirus type 5. The number of virus particles $/ 50 \%$ infective units varied from 10 to 100 with different preparations.

Infectivity titrations of adenoviruses are usually based on their cytopathic effect in cultures of HeLa cells and end-points, calculated from all-or-none responses, are given as the dilution of the preparation under test which gives a $50 \%$ response. It has been shown (Pereira \& Kelly, 1957) that the doseresponse curve of the infective action of adenovirus type 5 in HeLa cells is consistent with the hypothesis of independent action of infective units, a single unit being sufficient to initiate infection. The present investigation was designed to determine the relation between these infective units and electron microscope counts of the numbers of virus particles.

\section{METHODS}

Virus strain. The prototype strain of adenovirus type 5 was received from Dr R. J. Huebner (National Institutes of Health, Bethesda, Maryland, U.S.A.) and propagated in HeLa cell cultures. The materials used in the present study consisted of pooled cells from cultures showing advanced cytopathic effect. Each pool contained cells either from ten bottles (each with about $10^{7}$ cells at the time of inoculation) or from 200 to 300 tubes used in routine titrations of the strain under study.

Virus purification. The method used was based on the technique described by Gessler, Bender \& Parkinson (1956). Pooled cells were washed with $25 \mathrm{ml}$. distilled water and centrifuged at $600 \mathrm{~g}$ for $10 \mathrm{~min}$. The supernatant fluid was discarded and the packed cells resuspended in $2 \mathrm{ml}$. of $\mathrm{M} / 15$ phosphate buffer ( $\mathrm{pH} \mathrm{7 \cdot 3)}$. This suspension was added to $4 \mathrm{ml}$. of Arcton 63 (Imperial Chemical Industries, London, S.W.1) and homogenized in an M.S.E. universal container blender for 2 min. at maximum speed. The homogenate was centrifuged for $10 \mathrm{~min}$. at $600 \mathrm{~g}$ and the aqueous fraction decanted and saved. Another $2 \mathrm{ml}$. volume of phosphate buffer was added to the cell + Arcton fraction and followed by homogenization and centrifugation as above. This process was repeated a third time and the three aqueous fractions were pooled. The material obtained was opalescent, and when examined in the electron microscope was seen to contain a considerable amount of amorphous debris in addition to the virus particles. Further purification was achieved by submitting this material to several cycles of freezing at $-10^{\circ}$ and thawing at $37^{\circ}$. 
At each cycle a precipitate formed and this was separated by centrifugation at $1000 \mathrm{~g}$ for $10 \mathrm{~min}$., without measurable loss of virus activity. Three or four cycles of freezing and thawing were usually sufficient to yield almost waterclear preparations suitable for spray counts in the electron microscope (see Pl. 1).

Virus titrations. These were performed in cultures of HeLa cells propagated and maintained by methods previously described (Pereira \& Kelly, 1957). Virus dilutions were made in broth saline (10\% tryptic digest broth in normal saline) at 0.5 log steps, using a fresh pipette for each dilution. Volumes of $0.1 \mathrm{ml}$. of appropriate dilutions were inoculated into each of 4 cultures of HeLa cells which were incubated without rotation at $37^{\circ}$ for 27 days, with 3 fluid changes at intervals of 6 to 7 days. The $50 \%$ end-point was obtained by the method of Reed \& Muench (1938), and recorded as the number of $50 \%$ tissue culture doses (TCD 50)/ml. The standard error of each titration was calculated according to Pizzi's (1950) formula.

Table 1. Particle counts and infectivity titres of adenoviruses type 5

$\begin{array}{cccc}\text { Material } & \begin{array}{c}\text { Particles } / \mathrm{ml} . \\ \left(\times 10^{10}\right)\end{array} & \begin{array}{c}\text { Infective doses/ } \\ \text { ml. }\left(\times 10^{10}\right)\end{array} & \begin{array}{c}\text { Particles/ } \\ \text { infective dose }\end{array} \\ \text { H554-c } & 6 \cdot 5 & 0 \cdot 10 & 65 \\ \text { H554 } & 6 \cdot 8 & 0 \cdot 68 & 10 \\ \text { H565 } & 37 \cdot 4 & 0 \cdot 46^{*} & 82 \\ \text { H566 } & 20 \cdot 7 & 0 \cdot 20^{*} & 103 \\ & \text { * From geometric mean of two titrations. }\end{array}$

Particle counts. The purified virus preparations were mixed with equal volumes of an aqueous suspension of polystyrene latex spheres of diameter $0 \cdot 16 \mu$ (Dow Chemical Company: Lot no. LS 055 A). The latex suspension had a count of $1.0 \times 10^{11}$ particles $/ \mathrm{ml}$. as determined from its dry weight, the known density $\left(1.05 \mathrm{~g} . / \mathrm{cm} .{ }^{3}\right)$ of the spheres and their diameter which was measured in terms of the spacing of an aluminium replica of a standard ruling. Bovine albumin was added to the mixture $(0.05 \%, \mathrm{w} / \mathrm{v})$ which was then sprayed in the usual way (Williams \& Backus, 1949; Backus \& Williams, 1950) on to carbon films carried on electron microscope specimen supports. These were lightly shadowed with palladium and photographs were taken of the microdroplets at a magnification of $\times 7,000$. The virus particles could be clearly identified as electron-dense spheres of $c .70 \mathrm{~m} \mu$. diameter and the ratio of the count of these particles to the count of the latex particles was determined. The counts were checked for randomness and statistical significance by the method given by Luria, Williams \& Backus (1951).

\section{RESULTS}

Infectivity titres and particle counts obtained from four virus preparations are recorded in Table 1 . The standard errors of the particle counts varied between 10 and $20 \%$ and those of the infectivity titrations between $0 \cdot 18$ and $0 \cdot 30 \log _{10}$ units. 
The mean number of virus particles/infective dose ranged from 10 to 103 . This variation may be due to differences in sensitivity of separate batches of HeLa cell cultures. It is also possible that the different preparations used contained varying proportions of inactive virus particles, as no special precautions were taken to insure maximum infectivity of the starting materials. Preliminary experiments had shown that infectivity titres of adenovirus type 5 were not significantly decreased by the Arcton 63 treatment described above.

\section{COMMENTS}

The numbers of virus particles/infective dose obtained in the present study are very similar to the corresponding values found for other animal viruses (Isaacs, 1957; Schwerdt \& Fogh, 1957; Dumbell, Downie \& Valentine, 1957). They differ, however, from the ratio of $10^{4}$ particles/TCD50 of adenovirus type 4, reported by Tousimis \& Hilleman (quoted by Tousimis \& Hilleman, 1957). This discrepancy is rather too large to be due to differences in the properties of the two virus types and is probably accounted for by the short period of incubation ( 3 days) of the test cultures in the titration technique used by Tousimis \& Hilleman. The sensitivity of adenovirus titrations in HeLa cells varies greatly with the length of this period of incubation and maximum titres are reached only after incubation for 3-4 weeks (Pereira, unpublished).

We wish to thank Mr D. J. McGillicuddy for valuable technical help.

\section{REFERENCES}

BaCkUs, R. C. \& Williams, R. C. (1950). The use of spraying methods and of volatile suspending media in the preparation of specimens for electron microscopy. J. appl. Phys. 21, 11.

Dumbell, K. R., Downie, A. W. \& Valentine, R. C. (1957). The ratio of the number of virus particles to infective titre of cowpox and vaccinia virus suspensions. Virology, 4, 467.

Gessler, A. E., Bender, C. E. \& Parikinson, M. C. (1956). A new rapid method for isolating viruses by selective fluorocarbon deproteinization. Trans. N.Y. Acad. Sci. 18, 701 .

Issacs, A. (1957). Particle counts and infectivity titrations for animals viruses. Advance. Virus Res. 4, 111.

Luria, S. E., Williams, R. C. \& Backus, R. C. (1951). Electron micrographic counts of bacteriophage particles. J. Bact. 61, 179.

Pereira, H. G. \& Keldy, B. (1957). Dose-response curves of toxic and infective actions of adenovirus in HeLa cell cultures. J. gen. Microbiol. 17, 517.

Przzr, M. (1950). Sampling variation of the fifty per cent end-point, determined by the Reed-Muench (Behrens) method. Human Biol. 22, 151.

Reed, L. J. \& Muench, H. (1938). A simple method of estimating fifty per cent end points. Amer. J. Hyg. 27, 483.

Schwerdt, C. E. \& FoGH, J. (1957). The ratio of physical particles per infectious unit observed for poliomyelitis viruses. Virology, 4, 41.

Tousimis, A. J. \& Hirleman, M. R. (1957). Electron microscopy of type 4 adenovirus strain RI-67. Virology, 4, 499. 

Journal of General Microbiology, Vol. 19, No. 1

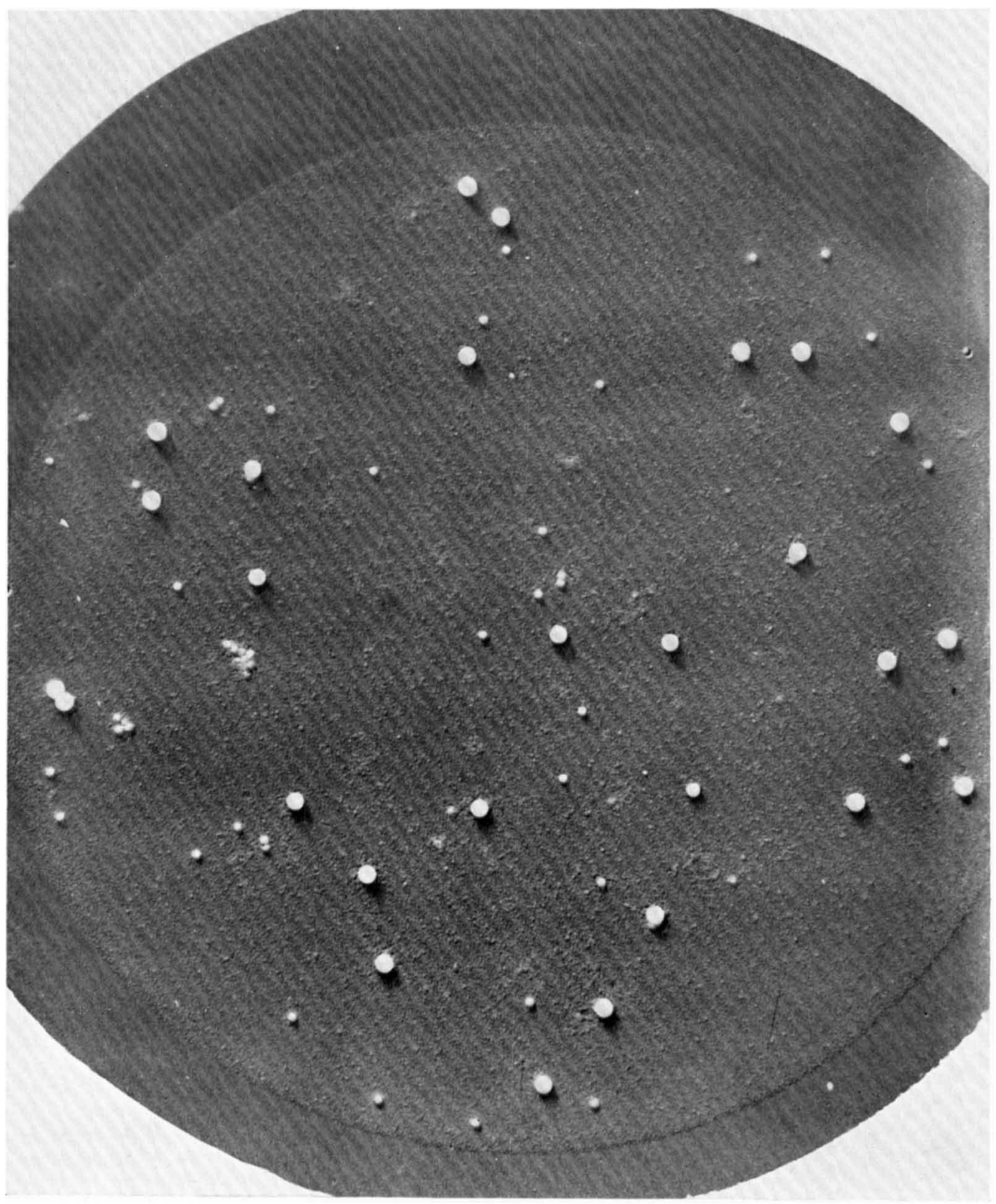

H. G. Perktra \& R. C. Valentinle-Adenovikus particle counts. Plate 1

(Facing $p .181$ ) 
Williams, R. C. \& Backus, R. C. (1949). Macromolecular weights determined by direct particle counting. I. The weight of the bushy-stunt virus particle. $J$. Amer. chem. Soc. 71, 4052.

\section{EXPLANATION OF PLATE}

Electron micrograph of a typical spray droplet used in making the virus particle count. The larger spheres are the latex indicator particles $(0.16 \mu$ diameter) and the smaller dense objects (c. $70 \mathrm{~m} \mu$ diameter) the adenovirus particles. The droplets were metal shadowed with palladium. $\times 16,000$.

(Received 18 February 1958) 